Book Power in Communication, Sociology and Technology

Ed. Angela Repanovici, Manolis Koukourakis, Tereza Khecyoyan

Series: Philosophy, Communication, Media Sciences

TRIVENT

Available online at http://trivent-publishing.eu/

\title{
Reading for Life: Biblio/Poetry Therapy with Different Target Groups
}

\author{
Judit Béres \\ University of Pécs (Faculty of Arts \& Humanities, Department of Culture, \\ Library \& Social Sciences), Hungary, beresjudit76@gmail.com
}

\begin{abstract}
This chapter aims to give a general overview of the theoretical and practical background of person-centred group biblio/poetry therapy, and introduces the 'Pécs School' (Hungary) which represents this field. The author summarizes some opportunities of biblio/poetry therapy offered to different target groups, facilitated by professionals trained in Pécs. This work is based on books and other text-like materials used as mental health tools to spark interactive and (self)reflective reading, writing, and discussion that promote personal growth, and improve positive outcomes for people of various gender and age groups in different social contexts, living with mental health and emotional wellbeing issues.
\end{abstract}

Keywords: bibliotherapy; poetry therapy; therapeutic reading; therapeutic writing; mental health; emotional wellbeing; person-centred approach.

DOI: 10.22618/TP.PCMS.20181.156010

This is an Open Access article distributed in accordance with the Creative Commons Attribution Non Commercial (CC-BY-NC-ND 4.0) license, which permits others to copy or share the article, provided original work is properly cited and that this is not done for commercial purposes. Users may not remix, transform, or build upon the material and may not distribute the modified material (http:/ / creativecommons.org/ licenses/by-nc/4.0/) 


\title{
Reading for Life: Biblio/Poetry Therapy with Different Target Groups
}

\author{
Judit Béres \\ University of Pécs (Faculty of Arts \& Humanities, Department of Culture, \\ Library \& Social Sciences), Hungary
}

\section{Introduction}

In his book titled $A$ History of Reading, Alberto Manguel emphasizes how deeply reading (as a practice of understanding and interpretation of any - not just literally written - signs) is essentially embedded in human culture and everyday life. "We all read ourselves and the world around us in order to glimpse what and where we are. We read to understand, or to begin to understand. Reading, almost as much as breathing, is our essential function."1 Reading ourselves, reading as self-exploration and self-understanding strongly links to the process of self-cognition, identification, evaluation and self-assessment. How we develop this metaphorical self-reading is one of the most complex and mysterious aspects of biblio/poetry therapy, when reading and writing ourselves, Others and the world supports self-understanding and helps the person to gain insight and motivation for change.

In her impressing autobiographical novel, Why Be Happy When You Could Be Normal?, Jeannette Winterson highlights this relationship based on the expressive and healing power of words: "I believe in fiction and the power of stories because that way we speak in tongues. We are not silenced. All of us, when in deep trauma, find we hesitate, we stammer; there are long pauses in our speech. The thing is stuck. We get our language back through the language of others. We can turn to the poem. We can open the book. Somebody has been there for us and deep-dived the words." 2 Reading and writing can help us to express difficult emotional experiences when turning the emotional content into language. ${ }^{3}$ The act of turning or transforming emotional experiences into words allows us to give structure to something unstructured (and many times unconscious) that helps to get more control over it. From this new perspective, and in the mirror of others, we can start to understand and re-evaluate our experiences in a new light. "Materials [that we read and write] create new perceptions in relationship to the readers' selves, others, and the world. The creative focus is within self, creating new feelings, new attitudes and new motivations for action." 4 This is the starting point of our work in biblio/poetry therapy.

\footnotetext{
1 Alberto Manguel, $A$ History of Reading (New York: Penguin Books, 1997), 7.

2 Jeanette Winterson, Why Be Happy When You Could Be Normal? (Toronto: Vintage Canada, 2012), 9.

${ }^{3}$ James W. Pennebaker, J. F. Evans, Expressive Writing: Words that Heal (New York: Idyll Arbor, 2014).

4 Arleen M. Hynes, "Some Observations on Process in Biblio/poetry Therapy", The Arts in Psychotherapy 8 (1981): 237.
} 


\section{Reading and writing in biblio/poetry therapy}

Biblio/poetry therapy is the interactive, facilitated use of (self)reflective reading and writing that helps people tackle their own subject matter, promotes personal growth, and supports mental health and wellbeing.

\section{(Self) reflective reading in biblio/poetry therapy}

Bibliotherapy is based on classical psychotherapy principles of identification, inspiration and insight which leads to motivation for positive change. This can help readers gain insight into themselves by connecting with characters and values appearing in poems, short stories, novels or in other textual materials. Their reading is followed up with group discussion and facilitated by the bibliotherapist's and group mates' questions and reflections. Group members can share their ideas and feelings with the help of the expression of their own subjective response to the text shaped by their identity and life-experience. The aim of the therapy is to elicite change in the attitudes and behaviour of the readers to enhance their problem-solving skills, and hence increase their resourcefulness. It aims to show readers that they are not alone because the others have the same concerns or problems. The main goal of the therapeutic process is positive life-change and personal development. ${ }^{5}$

"Bibliotherapy is the use of reading creatively; books, stories and poems to make people feel better, in themselves, about themselves and about others. (...) We all know how reading can take us out of ourselves and into another world. Conversely it can show us our own life mirrored in that of another person. If we are feeling miserable or alone sharing our experience in this way can help us to feel less isolated. Our empathy with others is extended as is our imagination and understanding." 6 As Julie Walker, a brilliant British psychiatric nurse-bibliotherapist-adult educator argues, "bibliotherapy supports people to take control of their own health and emotional wellbeing, and helps building resilience. It fits with secondary level preventions/interventions by promoting opportunities for increasing coping skills and helps to alleviate symptoms of depression and anxiety, increase self-esteem, improve social skills and concentration, combat isolation, and provide access to deeper thoughts and feelings and the words to express these to others." 7

A wide range of fiction and non-fiction materials are appropriate for biblio/poetry therapy purposes that meet the users' needs and the focus of the therapy. Textual materials serve as motivating, affirming and empowering mental health tools. The following types of texts or other materials (that can be interpreted as texts or stories) are among them:

- fiction books and texts - classic and contemporary imaginative literature: poetry, short stories, novels, drama, fairy tales

- other imaginative or semi-imaginative genres: song lyrics, chick lit, theme-appropriate movies, dreams, traditional folk tales, Hasidic tales, therapeutic and developmental stories (e.g. written by Nancy Davis or Annamária Kádár)

5Judit Béres, "Bibliotherapy and Creative Writing", in Horizontok II. A pedagógusképzés reformjának folytatása, ed. Ferenc Arató (Pécs: PTE BTK Neveléstudományi Intézet, 2015), 190.

6 John Duffy, Jo Haslam, Lesley Holl \& Julie Walker, Bibliotherapy Toolkit (Huddersfield: Kirklees Council - NHS, 2012), 3.

7 Julie Walker, Does Bibliotherapy Work? Posted on 17 December 2014.

http://www.cilip.org.uk/blog/does-bibliotherapy-work 
- non-fiction: documentaries, letters, diaries, philosophy, case histories, autobiographies, personal recovery stories (e.g. AA, NA), self-help books, personal Facebook posts and blogs. ${ }^{8}$

\section{(Self) reflective writing in biblio/poetry therapy}

As "reading ourselves" is of key importance in biblio/poetry therapy, self-writing also belongs to the bibliotherapist's basic toolkit. Nowadays there are some national practices of biblio/poetry therapy (e.g. in Finland, Lithuania, United Kingdom and the USA) where creative, poetic methods and the different types of personal writing are often more important tools than reading and reception of books. The dialogue of two professionals, Gillie Bolton, the British creative writing trainer and Juhani Ihanus, a Finnish poetpsychologist-poetry therapist highlights why the application of writing is important in therapy: "Insight and support are gained by writing that help us find out more about ourselves and the way we relate to home and work, significant others, and wider society and culture. It offers relatively safe and confidential ways to express areas of experience otherwise difficult to communicate. In its initial expressive and explorative stages, writing is private, and is both physical and creative, as is art, music, and dance." 9

Besides receptive/prescriptive biblio/poetry therapy when working with personal readings/meanings of already existing texts (e.g. poems, lyrics, novels written by other authors), poetic methods are often applied in bibliotherapeutic work. Poetic methods such as poetry, letter or journal writing foster participants' self-assessment, encourage selfexpression, provide a sense of order and control, and promote group process variables such as cohesion. ${ }^{10}$

Explorative, expressive writing is a proper way of self-writing applied in biblio/poetry therapy. Expressive writing is a powerful and deeply personal, mostly free style and fluent text (many times with no grammar, syntax or much sense) that helps people to confront deep, personal issues, promoting physical health and subjective wellbeing. This writing is a tool to 'translate' into language traumatic, disturbing emotional experiences that people suffer from. ${ }^{11}$

Self-writing applied in biblio/poetry therapy is a kind of personally developing, deeply self-reflective therapeutic writing. Gillie Bolton mentions poetry, journal and autobiographical writing that can reduce self-consciousness, allowing writers to tap into their strong wise creative sides "Whatever you write will be right for you at that time. Although possibly initially unclear or lacking in understanding, we are the world's best authorities on our own experience and so cannot write wrongly about it."12 This writing enhances self-understanding, enables the person to express experiences, thoughts and feelings difficult or impossible to share directly with others. Therapeutic writing improves

\footnotetext{
${ }^{8}$ Categories and genres of materials applied in biblio/poetry therapy are based on Nicholas Mazza, Poetry Therapy: Theory and practice (New York: Brunner-Routledge, 2003); John C. Norcross et al., SelfHelp That Works. Resources to Improve Mental Health and Strenghten Relationships. $4^{\text {th }}$ ed. New York: Oxford University Press, 2013); Judit Béres, "Azért olvasok, hogy éljek. Az olvasásnépszerüsitéstól az irodalomterápiáig ["I read for my life" From reading promotion to biblio/poetry therapy](Pécs: Kronosz, 2017)

9 Gillie Bolton, Juhani Ihanus, "Conversation about poetry/writing therapy: Two European perspectives", Journal of Poetry Therapy 24, (2011): 3. 169. See more about reflective writing applied in counselling and psychotherapy: Jeannie Wright, Gillie Bolton, Reflective Writing in Counselling and Psychotherapy (London: SAGE Publications, 2012)

${ }^{10}$ Nicholas Mazza, Poetry Therapy

${ }^{11}$ James W. Pennebaker, J. F. Evans, Expressive Writing

12 Gillie Bolton, Juhani Ihanus, "Conversation”, 170.
} 
self-respect, personal integrity and positive regard, in order to discover appropriate ways to act in the future. Even if this writing is originally for its writer to read, s/he has full authority over it, including rereading alone or possibly sharing with trusted persons. Personal writings created by participants during the sessions and after the sessions, at home, may be applied as other textual materials, if brought back and shared with trusted group members, and become subject of reflections and discussion.

\section{Person-centred biblio/poetry therapy}

In February 2014 the University of Pécs started a continuing professional training programme in biblio/poetry therapy which has become the Hungarian centre of the personcentred approach. Nowadays it is the major and most successful centre of Hungarian education in bibliotherapy.

The aim of this training programme is to offer advanced knowledge and skills in the fields of biblio/poetry therapy, reading and writing for mental health and wellbeing. On completion of the qualification the trainees will be able to plan and facilitate the interactive use of imaginative literature, non-fiction materials and therapeutic writing, promoting personal growth for people from various age groups in different social contexts, living with mental health and emotional wellbeing issues.

Through the whole programme students receive intensive instruction in major disciplinary fields necessary for bibliotherapist practitioners working in developmental or clinical context, such as the basics of psychotherapy and mental health, group dynamics, selection and interactive use of materials, bibliotherapy for special target groups, and supervision. 100 hours of peer experience as a participant in a supportive therapy group is an essential part of the training programme. Bibliotherapy workshops and field visits offered as further opportunities for exploring the benefits of various facilitation techniques.

Biblio/poetry therapy represented by the 'Pécs School' is person-centered in character. However books and other textual materials are key tools and important points of reference in biblio/poetry therapy, therapy itself does not derive just from the book. ${ }^{13}$ The strongest power of bibliotherapy is based on intrapsychic and interpersonal processes. This fact fostered the notion of group process- and person-centered biblio/poetry therapy that places emphasis on participants' therapeutic experience, examining therapeutic reading as a group process phenomenon. ${ }^{14}$ Participants' emotional experiences and interpersonal processes between them are central, taking into consideration the wide range of therapeutic factors. Dealing with multiple emotional factors through a person-centered bibliotherapeutic process, that results an integrative model of bibliotherapy, based on the so called 'personcentred approach' applied in the humanistic psychology.

This model offers a view of people as active, autonomous agents of the improvement of their own life who, through deep encounters and intimate exchanges with the materials, the facilitator and each other, evolve an emotionally supportive environment in the bibliotherapy group, a net of interpersonal processes. A set of activities for developing EQ are involved in this process like, for instance, becoming capable to perceive, express and understand one's emotions and ideas, capability to share personal emotional experiences, acceptance of ourselves and others, practice of giving and getting support and feedback.

\footnotetext{
13 About the distinction between the positive emotional effect of a good book and bibliotherapy, see more in Keren Dali, "On Bibliotherapy", Reader's Advisory News, August 2014. https://www.ebscohost.com/novelist/novelist-special/on-bibliotherapy (accessed April 29, 2016)

${ }^{14}$ Laura G. Cohen, "Reading as a Group Process Phenomenon. A Theoretical Framework for Bibliotherapy", Journal of Poetry Therapy 3 (1989): 2, 73-83.
} 
Among these dynamic processes the influence of the readings or other materials is just one factor which is not enough to make an effective therapy.

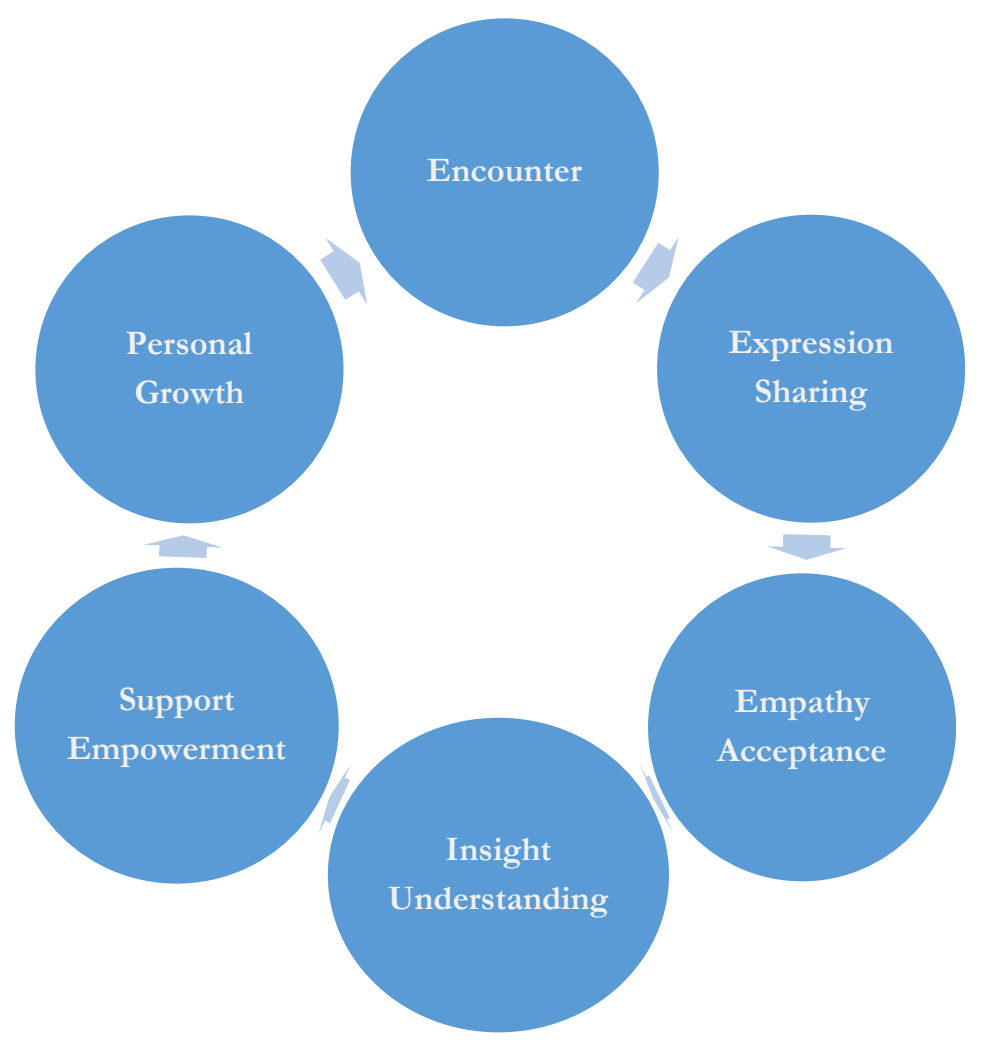

Fig. 1. Emotional processes in person-centered group biblio/poetry therapy ${ }^{15}$

Given this model is person-centred it suggests to deal with some potentials hidden within and between the participant persons. The readings (or other text-like materials as I mentioned before) elicit participants' subjective emotional response shaped by their identity and life-experience, offering a tool for their projections. One of the main questions of bibliotherapy is about why the certain person responds to literary works and other materials as $\mathrm{s} /$ he does, and how her/his introjections shape the personal interpretation of the materials. Thus enables the participant to stand both inside and outside that interpretation so as to observe and understand it. This act of insight, accompanied by group interactions and co-constructions of meanings might lead the person to new attitudes and new motivations for action. ${ }^{16}$

${ }^{15}$ Judit Béres, "Person-centered Bibliotherapy", in Reading for Recovery poster series. ed. Judit H. Ward, J. $38^{\text {th }}$ Annual Conference of the Substance Abuse Librarians \& Information Specialists and Association of Mental Health Librarians (Denver, CO, May 5, 2016)

16 As I mentioned earlier, according to Hynes, 1981. 


\section{Biblio/poetry therapy as a tool for helping professionals}

Since Clara Richardson Lack's famous article (Can Bibliotherapy Go Public? ${ }^{17}$ has been published, it is a widespread idea that bibliotherapy can be divided in two types, developmental and clinical bibliotherapy. In Hungary there are shorter bibliotherapy trainings which try to focus just on developmental bibliotherapy education for librarians and teachers. The 'Pécs School' does not share this idea as it happens many times that the two modality (developmental and clinical) cannot be separated clearly during the therapeutic work. That is why we prepare trainees for the challenges of both fields, and teach them general skills needed in the facilitation of group bibliotherapy. Finally it depends from trainees original professional competences, how, with whom and where they will apply bibliotherapy. ${ }^{18}$

Biblio/poetry therapy is an effective method adaptable in many helper professions, which might be added to the toolkit of professionals who work for humans' support. It may be offered for different target groups, both in clinical and non-clinical settings. This is why the biblio/poetry postgraduate training of the University of Pécs is available for BA or MA degree holders in arts and humanities, teacher training, mental health care, medical sciences, economy, law, and pastoration. Our students are professionals who already work with humans in different settings, and intend to learn a new method to be involved in their work. The list of their professions and typical working places is the following:

- teacher in public (elementary or high) school or adult education institutions;

- librarian in school, public and medical libraries;

- social worker in day-care centres and care homes for people living with substance abuse issue (e.g. drugs and alcohol), working in rehab centres and relapse prevention; -social worker and mental health worker working with elderly people in care homes or in other settings (e.g. clubs for elderly, open universities for seniors);

-social worker or volunteer from social welfare services, crisis intervention centres, shelter houses, or hospitals;

- life and business coach who has both individual and group sessions with their clients;

- HR professionals (e.g. head hunter, human resource \& career manager);

- prison and school psychologist;

- clinical psychologist working in hospitals (e.g. with children and mothers-to-be);

- assistant, counsellor or special educator working in family therapy, bereavement counselling and palliative rehabilitation;

- psychiatrist working with adolescents or adults in psychiatric wards.

This list implicates the main types of the available target groups (such as students, library users, psychiatric patients, addicts etc.), but in reality there are much more types of potential clients in one setting that we could imagine for first.

In schools, for instance, teachers trained in bibliotherapy or outsider bibliotherapists work mostly with students. This means the application of some elements of biblio/peotry therapy in classroom work. Teachers and school librarians sometimes offer biblio/poetry therapy groups as parents support, and there is also bibliosupervision support for teachers' burn-out prevention. Some schools have special classes for disadvantaged and/or gifted students for whom biblio/poetry therapy sessions are among cross-curricular support programmes. Table 1 shows the details of this kind of biblio/poetry therapy provided for 3

${ }^{17}$ Clara Richardson Lack, "Can Bibliotherapy Go Public?”, Collection Building, 1985 Spring, 27-32.

${ }^{18}$ The 'Pécs School' shares the integrative approach of the creative bibliotherapy programme titled "Well into words" provided by the Kirklees Council, National Health Service, United Kingdom. https://vimeo.com/70929838 
months (1,5 hours every second week, with one facilitator) in the club of a high school in Pécs.

Table 1. Biblio/poetry therapy for disadvantaged gifted adolescents

\begin{tabular}{|c|c|c|}
\hline Topics discussed & Materials & Creative tasks \\
\hline $\begin{array}{l}\text { holding and caring in human } \\
\text { relationships, love, patience, values, } \\
\text { Christmas in our family (the group } \\
\text { started in Christmas period) }\end{array}$ & $\begin{array}{l}\text { János Pilinszky: Hitünk } \\
\text { titkairól (Advent) [Secrets } \\
\text { of our religion] (essay) }\end{array}$ & $\begin{array}{l}\text { Petra Finy: Bemutatkozom [I } \\
\text { introduce myself] (poem); write } 5 \\
\text { characteristics about how you see } \\
\text { yourself }+5 \text { as Others might see } \\
\text { you }\end{array}$ \\
\hline $\begin{array}{l}\text { self-confidence, giftedness, emotional } \\
\text { resourcefulness, resilience }\end{array}$ & $\begin{array}{l}\text { Lotilko szárnyai [The } \\
\text { wings of Lotilko] (Tunguz } \\
\text { folktale) }\end{array}$ & $\begin{array}{l}\text { read Ágnes Ágai's adolescent } \\
\text { poems, write a similar poem } \\
\text { about yourself }\end{array}$ \\
\hline $\begin{array}{l}\text { daydreams, desires, plans, career \& } \\
\text { identity }\end{array}$ & $\begin{array}{l}\text { Frigyes Karinthy: } \\
\text { Találkozás egy } \\
\text { fiatalemberrel [Meeting } \\
\text { with a young man] (short } \\
\text { story) }\end{array}$ & $\begin{array}{l}\text { write a letter with } \\
\text { recommendations to the } 8-9 \text { years } \\
\text { younger yourself }\end{array}$ \\
\hline $\begin{array}{l}\text { supportive/destructive relationships } \\
\text { (family, love, friendships), barriers, } \\
\text { coping }\end{array}$ & $\begin{array}{l}\text { Ervin Lázár: A kalapba } \\
\text { zárt lány [The girl closed } \\
\text { in a hat] (tale) }\end{array}$ & $\begin{array}{l}\text { write sms letters similarly to } \\
\text { Dániel Varró's Szívdesszert } \\
\text { [Heart dessert] (poem) }\end{array}$ \\
\hline $\begin{array}{l}\text { role models, youth trends, } \\
\text { positive/negative self-image, body } \\
\text { image }\end{array}$ & $\begin{array}{l}\text { Krisztina Tóth: A lélek } \\
\text { megatest [The Soul is } \\
\text { Megabody] (short story) }\end{array}$ & $\begin{array}{l}\text { write an advertisement about } \\
\text { yourself similar to Virág Erdős' } \\
\text { Hazudós mese [Liar tale] (poem) }\end{array}$ \\
\hline $\begin{array}{l}\text { happiness, successful life, self- } \\
\text { criticism, inner resources }\end{array}$ & $\begin{array}{l}\text { Sándor Márai: Füves } \\
\text { könyv - A boldogságról } \\
\text { [Herbarium (About } \\
\text { happiness)]; Sándor } \\
\text { Weöres: A teljesség felé } \\
\text { (A forrás - } \\
\text { Szembefordított tükrök) } \\
\text { [Toward completeness } \\
\text { (The source - Mirrors } \\
\text { facing each other)] } \\
\text { (philosophy) }\end{array}$ & $\begin{array}{l}\text { final evaluation with association } \\
\text { Dixit Cards }\end{array}$ \\
\hline
\end{tabular}

This table gives a much clearer picture of what we do and how it works. In Hungary we started bibliotherapy programs in three types of secondary schools (vocational school, technical college, grammar school for gifted children), with implications for the reduction of socio-emotional risks and distress of disadvantaged students. ${ }^{19}$ In this work particular attention is given to how bibliotherapy can facilitate readers to find solutions to personal problems, develop life skills and enhanced self-image. Bibliotherapy helps these students to learn new strategies for dealing with their social and emotional issues, and supports their empowerment, that is to break out of disadvantages and work out opportunities based on their understanding. Whilst working together in a bibliotherapy group, students learn about themselves and understand that they are not alone, but others have been sharing - and had

\footnotetext{
${ }^{19}$ See more details in Judit Béres, Ildikó Sóron, Tünde Tegzes, Borbála Zsidai, „Hátrányos helyzetû középiskolások biblioterápiája" [Bibliotherapy for disadvantaged youth], Könyvtári Figyelo", (2014): 4, 459-480.; Judit Béres, Bibliotherapy and Creative writing.
} 
shared - the same concerns or problems. This can expose them to new ways of thinking about and seeing the world around them, helps them gain insight by connecting to each other, to a sentence in a poem or song lyrics, or by identifying with a character in a novel or short story with similar issues to overcome. Creative writing played a very important role in this therapeutic work. We usually applied warm-up identity plays from the collections, and used humorous and ironic model texts from Hungarian poets, asking students to write similar, strong messages about themselves. This helped them to understand motivations, express feelings, externalise selfhood, reduce loneliness, frustration, and distress. ${ }^{20}$

Opportunities are usually numerous in all settings we apply biblio/poetry therapy. My second example is about libraries as traditional institutions related to the service of people, reading and books offer also numerous opportunities for general biblio/poetry groups aiming at healthy population and at people living with mild and moderate mental health and wellbeing issues. The biggest part of these groups are organised for the general support of people from various gender and age groups. There are also special, thematic groups that focus on special questions or turning points in everyday life situations (e.g. unemployment, problems in intimate partnerships and other relationships / between husband-wife, parentchild, siblings, different generations/. Thematic groups are available for vulnerable people or for those who deal with identity issues and new developmental tasks (women, young mothers and fathers, elderly, professionals in career change, immigrants). Other thematic groups focus on the support of clients with primary bonding and loss issues (e.g. divorce, bereavement, parents-to-be, parents with little children, and parents who have to let go their young adult children). Table 2 gives insight into the work of a 14-month-long ( 2 hours once per month in a quiet room of the county library, with one facilitator) biblio/poetry process supporting 10 adult women from different age groups (from 23 to 63), all of them facing normative life-crises and emotional wellbeing issues.

Table 2. Bibliotherapy for adult women with normative life-crises

\begin{tabular}{|l|l|l|}
\hline Topics discussed & Materials & Creative tasks \\
\hline $\begin{array}{l}\text { current mood and life situations, } \\
\text { challenges, expectations }\end{array}$ & $\begin{array}{l}\text { Virág Erdős: Ma [Today] } \\
\text { (poem) }\end{array}$ & - \\
\hline $\begin{array}{l}\text { female/male role models, } \\
\text { marriage/partnership crises, self- } \\
\text { esteem, daydreams and desires }\end{array}$ & $\begin{array}{l}\text { Lyudmila Ulitskaya: } \\
\text { Szonyecska [Sonechka] } \\
\text { (novel) }\end{array}$ & $\begin{array}{l}\text { (home work) creative writing } \\
\text { about the therapeutic situation } \\
\text { (diary, poem, free style text) }\end{array}$ \\
\hline $\begin{array}{l}\text { attachment, separation, loss, } \\
\text { reflectivity, self-reflection, self- } \\
\text { esteem, self-confidence, primary and } \\
\text { secondary bondings }\end{array}$ & $\begin{array}{l}\text { Eszter Szakács: Saudade; } \\
\text { Anna T. Szabó: Elhagy } \\
\text { [She leaves me] (poems) }\end{array}$ & $\begin{array}{l}\text { (home work) reflective writing: } \\
\text { the woman in the mirror who I } \\
\text { am... }\end{array}$ \\
\hline $\begin{array}{l}\text { female identity, construction of } \\
\text { femininity, trans identity, sexuality, } \\
\text { body }\end{array}$ & $\begin{array}{l}\text { Tibor Noé Kiss: } \\
\text { Inkognitó [ncognito] } \\
\text { (transvestite novel) }\end{array}$ & $\begin{array}{l}\text { entry with association cards (Bear } \\
\text { Cards); (home work) reflective } \\
\text { writing: my body, my femininity }\end{array}$ \\
\hline $\begin{array}{l}\text { role models, female identity, } \\
\text { femininity, self-esteem, body image }\end{array}$ & $\begin{array}{l}\text { Krisztina Tóth: A lélek } \\
\text { megatest [The Soul is } \\
\text { Megabody] (short story) }\end{array}$ & $\begin{array}{l}\text { (home work) expressive writing: } \\
\text { milestones of my personal growth }\end{array}$ \\
\hline
\end{tabular}

${ }^{20}$ See more details in Judit Béres, Bibliotherapy and Creative writing. 


\begin{tabular}{|c|c|c|}
\hline $\begin{array}{l}\text { creativity, independence, freedom, } \\
\text { love, loss }\end{array}$ & $\begin{array}{l}\text { Anna T. Szabó: Senki } \\
\text { madara [Bird of Noboby] } \\
\text { (short novel) }\end{array}$ & - \\
\hline $\begin{array}{l}\text { abusive relationships, domestic } \\
\text { violence, infertility, sexual } \\
\text { dependence }\end{array}$ & $\begin{array}{l}\text { Noémi Kiss: Sovány } \\
\text { angyalok [Thin Angels] } \\
\text { (novel) }\end{array}$ & - \\
\hline taboos, secrets, insight, trust, sharing & $\begin{array}{l}\text { Tímea Turi: A dolgok, } \\
\text { amikrôl nem beszélünk } \\
\text { [Things we never talk } \\
\text { about] (poem) }\end{array}$ & entry with association cards \\
\hline $\begin{array}{l}\text { women roles, touchstone members } \\
\text { of the family, conscious and } \\
\text { unconscious, trauma }\end{array}$ & $\begin{array}{l}\text { Lyudmila Ulitskaya: } \\
\text { Médea és gyermekei } \\
\text { [Medea and her children] } \\
\text { (novel); Életmúvésznők } \\
\text { [Women's Lies] (short } \\
\text { stories) }\end{array}$ & - \\
\hline $\begin{array}{l}\text { reading, writing and identity work, } \\
\text { mother-daughter relationship, } \\
\text { mothernity, lesbian identity }\end{array}$ & $\begin{array}{l}\text { Jeanette Winterson: Miért } \\
\text { lennél boldog, ha lehetsz } \\
\text { normális? [Why be happy } \\
\text { when you could be } \\
\text { normal] (lesbian, } \\
\text { autobiographic novel) }\end{array}$ & $\begin{array}{l}\text { send your favorite tale to group } \\
\text { members, guess choice } \\
\text { motivations }\end{array}$ \\
\hline $\begin{array}{l}\text { self-assessment, personal growth, } \\
\text { further developmental tasks }\end{array}$ & $\begin{array}{l}\text { János Szentmártoni: } \\
\text { Befejezhetetlen vers } \\
\text { önmagunk állásáról } \\
\text { [Unterminable poem } \\
\text { about ourselves]; Szilárd } \\
\text { Borbély: Ha menni kell [If } \\
\text { it’s time to go] (poems) }\end{array}$ & $\begin{array}{l}\text { creative writing: finish the poem } \\
\text { with self-reflection, share with } \\
\text { others }\end{array}$ \\
\hline
\end{tabular}

This group focused on the multiple experience of female identity and personal growth, supporting participants' coping skills when facing normative life-crises. The group worked for female empowerment (connected to feminist psychotherapy), improving women's positive self-evaluation and resilience, helping them achieving a sense of intimacy and generativity. The group offered a lifelong perspective in character as three different generations were present supporting each other, creating a flourishing context for interpersonal learning, understanding and acceptance. ${ }^{21}$ In May 2017 a similar, but a bit longer (15-month-long, 2 hours per month) biblio/poetry therapy group for women has been started in Pécs, held in a nice community setting with garden (not in library), facilitated by two bibliotherapists in cotherapy. In this new group we try to a de more person-centred, and emphasize the benefits of poetic methods applied in identity work (e.g. poetry writing, letter writing, journal writing, tale writing). The biggest part of our sessions is based on group members' personal writings prepared during the sessions or after sessions, at home. Receptive bibliotherapy (when we read already existing texts from poets and writers) is quite rarely applied, if yes, we use just small part units that may trigger self-reflection. Tools from fine art therapy and tale therapy (Metamorphoses) are also involved in this work. Since 2012 three other types of biblio/poetry group for women has been started in Pécs, one for elderly women at the open university for seniors held at the University of Pécs, another one

\footnotetext{
${ }^{21}$ See more details in Judit Béres, Bibliotherapy for Women from a Lifelong Learning Perspective, in Some Issues in Pedagogy and Methodology, eds. Judit Torgyik, János T. Karlowitz (Komárno: International Research Institute, 2016) 111-120.
} 
held in a crisis intervention care home for abused mothers with little children, and the third one started in a local prison. ${ }^{22}$

Concluding, it is worth mentioning some of the main benefits of biblio/poetry therapy. The group facilitator usually asks participants to fill out a final feedback questionnaire which helps participants' reflection on the most important factors of their therapeutic experience. According to participants' opinion:

1. Participants appreciated the 'sense of universality', they felt they are not alone suffering from the certain problems. With the help of the (self)reflections given to each other, to the texts and the facilitator they learnt how others see their personality and behaviour, how they solve similar problems, that helped to gain new perspectives and insights.

2. The group supported the inter/intragenerational communication, helped participants to understand others' way of thinking, motivations and reasons behind their communication and behaviour.

3. The group fostered self-reflection, the deeper understanding of experiences and personality (weaknesses, strengths) showing further developmental tasks.

4. Facilitators, group members and the self-reflective work sparked by personal writings and other theme-appropriate texts created a warm, positive and supportive emotional atmosphere, which was important experience, mostly for those who are lacking this basic 'holding' in their everyday relationships. This atmosphere empowered participants to be more active and autonomous agents of their own life.

5. Deep encounters with each other, the facilitators and the textual materials evolve a rich net of interpersonal and intrapsychic processes such as becoming capable to perceive, express and understand one's emotions and ideas, capability to identify and share personal contents, practice of giving and getting support and feedback, accept and tolerate others' values.

6. It was a great experience to discover the healing power of (self)reflective writing, finding inner creative resources.

As outlined previously, the biblio/poetry therapy model and the group programmes introduced here effectively use reflective, personal reading and writing as a life support system, offering great opportunities for people's mental health and wellbeing support, that result a number of positive emotional and cognitive changes, empowering clients through their whole life-span.

\section{References}

Béres, J., Csorba-Simon, E. "Biblioterápia nőknek” [Bibliotherapy for Women], Könyvtári Figyelö 61, (2015): 2, 178-195.

Béres, J., Sóron, I., Tegzes, T., Zsidai, B. ’Hátrányos helyzetű középiskolások biblioterápiája" [Bibliotherapy for disadvantaged youth], Könyvtári Figyelö, (2014): 4, 459_ 480.

Béres, J., Zoboki, R. Biblioterápia időseknek a pécsi Szenior Akadémián [Bibliotherapy for elderly at the Senior Academy of Pécs] in IX. Képzés és Gyakorlat Nemzettözzi

\footnotetext{
22 See more details in Judit Béres, Bibliotherapy for Women; Judit Béres, Eszter Csorba-Simon, "Biblioterápia nőknek" [Bibliotherapy for Women], Könyvtári Figyeló 61, (2015): 2, 178-195.; Judit Béres, Rita Zoboki, Biblioterápia időseknek a pécsi Szenior Akadémián [Bibliotherapy for elderly at the Senior Academy of Pécs] in IX. Képzés és Gyakorlat Nemzetközi Neveléstudományi Konferencia. Tanulmánykötet, ed. Bernadette Nagyházi, (Kaposvár: University of Kaposvár, Faculty of Education, 2015) 86-92.
} 
Neveléstudományi Konferencia. Tanulmánykötet, ed. Bernadette Nagyházi, 86-92. Kaposvár: University of Kaposvár, Faculty of Education, 2015.

Béres, Judit. "Azért olvasok, bogy éljek" Az olvasásnépszerüsitéstöl az irodalomterápiáig ["I read for my life" From reading promotion to biblio/poetry therapy]. Pécs: Kronosz, 2017. "Bibliotherapy and Creative Writing", in Horizontok II. A pedagógusképzés reformjának folytatása, ed. Ferenc Arató. Pécs: PTE BTK Neveléstudományi Intézet, 2015. . "Bibliotherapy for Women from a Lifelong Learning Perspective", in Some Issues in Pedagogy and Methodology, eds. Judit Torgyik, János T. Karlowitz, 111-120. Komárno: International Research Institute, 2016. "Person-centered Bibliotherapy." In Reading for Recovery poster series. ed. Judit H. Ward, J. 38 $8^{\text {th }}$ Annual Conference of the Substance Abuse Librarians \& Information Specialists and Association of Mental Health Librarians. Denver, CO, May 5, 2016.

Bolton, G. and J. Ihanus. "Conversation about poetry/writing therapy: Two European perspectives." Journal of Poetry Therapy 24 (2011): 3. 167-186.

Cohen, Laura G. "Reading as a Group Process Phenomenon. A Theoretical Framework for Bibliotherapy." Journal of Poetry Therapy 3 (1989): 2, 73-83.

Dali, Keren/ "On Bibliotherapy", Reader's Advisory News, August 2014. https://www.ebscohost.com/novelist/novelist-special/on-bibliotherapy (accessed April 29, 2016)

Duffy, J. and J. Haslam, L. Holl, J. Walker. Bibliotherapy Toolkit. Huddersfield: Kirklees Council - NHS, 2012.

Hynes, A. M. "Some Observations on Process in Biblio/poetry Therapy", The Arts in Psychotherapy 8 (1981): 237-241.

Lack, Clara Richardson. “Can Bibliotherapy Go Public?” Collection Building, 1985 Spring, 2732.

Manguel, Alberto. A History of Reading. New York: Penguin Books, 1997.

Mazza, Nicholas. Poetry Therapy: Theory and practice. New York: Brunner-Routledge, 2003.

Norcross, J. C. et al. Self-Help That Works. Resources to Improve Mental Health and Strenghten Relationships. $4^{\text {th }}$ ed. New York: Oxford University Press, 2013.

Pennebaker, J. W. and J. F. Evans. Expressive Writing: Words that Heal. New York: Idyll Arbor, 2014.

Walker, Julie. Does Bibliotherapy Work? Posted on 17 December 2014. http://www.cilip.org.uk/blog/does-bibliotherapy-work.

Winterson, Jeanette. Why Be Happy When You Could Be Normal? Toronto: Vintage Canada, 2012.

Wright, J. and G. Bolton. Reflective Writing in Counselling and Psychotherapy. London: SAGE Publications, 2012. 